\title{
Quality Parameters of Palm Olein, Palm Kernel Oil and its Blends Subjected to Thermal Stress using Photometric Technology
}

\author{
O. B. Imoisi, M. E. Ukhun, and E. E. Ikpe
}

\begin{abstract}
There is no much information regarding the partial replacement of palm olein with palm kernel oil. Palm olein mixed with palm kernel oil is commonly sold in Nigeria market today without proper blending and without determination of their suitability to consumer also ignorant of what ratio to be blended. Therefore, blends of palm olein (POL) and palm kernel oil (PKO) were formulated to assess their stability under elevated temperature using a fast, simple and reliable CDR palm oil tester photometric technology. The results were then compared with those obtained in POL. The blends studied were to investigate the effects of palm kernel oil partial replacement on the chemical stability of palm olein. the blends as partial replacement were missed in the ratio of PKO:POL(100:0), PKO:POL(80:20), PKO:POL(60:40) and POL:PKO(100:0), POL:PKO(80:20), POL:PKO(60:40). The $P O L, P K O$ and its blends were heated at 100,150 and $200^{\circ} \mathrm{C}$. The time of heating were 20,40 and $60 \mathrm{mins}$ respectively, making a total of 1 hour for heating without any frying operations. The physicochemical properties of the oil samples were fatty acid composition, free fatty acid, peroxide value, iodine value, anisidine value, cloud point, colour, melting point, viscosity and totox value were evaluated over heating time. Blending palm olein (POL) unsaturated oils with saturated (PKO) generally improved the parameters comparable to those demonstrated in palm olein (POL) and palm kernel oil alone. The result showed that as PKO was increased the concentration of saturated fatty acid also increased while unsaturated fatty acid decreased. Saturated oils were generally more stable to oxidation and less sensitive to thermal stress. Increase in the amount of PKO lead to reduction in FFA.
\end{abstract}

Index Terms - Blends, CDR palm oil tester, formulated, photometric technology, stability.

\section{INTRODUCTION}

Edible oils play important roles in the body such as being sources of essential fatty acids. Essential fatty acids are not synthesized in the body but must be imbibed via the diet to maintain cell membranes and perform other functions [1]

Based on the need to consume good diets and control health issues like cholesterol, diabetes, and heart disease, it is important to consume healthy edible oils. Consumers need meaningful and honest information to enable them to make informed choices of their diets and the types of oil they purchase and consume [2].

The trend towards the consumption of healthier foods has stimulated the search for alternative oils or methods for improving the quality of oils presently used in food

Published on October 30, 2020.

O. B. Imoisi, Nigerian Institute for Oil Palm Research, Nigeria. (e-mail: imoisib@gmail.com)

M. E. Ukhun, University of Benin, Nigeria

(e-mail: tamjele@yahoo.com) processing. This has led to the modification of naturally occurring oils to meet carefully designed specifications, usually based on nutritional, physical or chemical requirements. Improved edible oils can be produced by physically blending oils in order to modify their properties and improve the oil functionality and meet product specifications [3].

With the rising demand for natural products and emphasis on nutritional enrichment, blending of vegetable oils and fats has emerged as a way of producing edible oils devoid of chemical treatments and which possess natural flavour and acceptable nutritional value. The advantage of using blending as a means of modifying oils is that it is easy and less costly. More importantly, blending of oils serves to improve and enhance the nutritional quality of the oils by combining of oils into one, thereby improving their commercial viability [3].

Palm oil is an edible vegetable oil derived from the mesocarp of the fruit of the oil palm Elaeis guineensis Jacq [4]. Oil palm is an example of commercially important fruits which provide important edible oils. The palm fruit provides two distinctly different oils, one from the fleshy mesocarp mainly oleic and the other from the seed kernels mainly lauric or endosperm [5].

Recently palm olein has become the second most used dietary oil all over the world with a competitive price compared to other edible oils. Due to its high melting point, it is gaining due status and is rich in natural antioxidants and fat-soluble vitamins. It also possesses high oxidative stability and long shelf-life [6]. Palm olein is rich in $\beta$ carotene which helps to prevent liver and lung cancer [7]. It has has now gained worldwide acceptance due to its unique properties and versatile applications as well as the competitive traded price over other vegetable oils [8]. The acceptance of palm oil worldwide is due to its special characteristics that encourage its use in a wide range of end products.

Palm kernel oil is extracted from the seed of the oil palm Elasis guineensis jacq. Depending on where one lives, it may be difficult to obtain pure palm kernel oil, but products which contain this oil are commonly available [9]. This oil has a low health rating because it is high in saturated fatty acids and low in essential fatty acids, making it a poor addition to diet. Palm kernel oil is cheap and readily available in many regions, making it an economically attractive alternative to the healthier palm olein. Like other oils which are very high in saturated fat, palm kernel oil is typically solid at room

E. E. Ikpe, University of Uyo, Nigeria.

(e-mail: ikpeemmanueledidiong@yahoo.com) 
temperature, and it can withstand very high temperatures. In parts of Africa and Asia, it is commonly used as cooking oil, therefore the urgent need for modification.

For many years, modifications of original fats by means of direct blending with other oils, fractionation, hydrogenation and inter- esterification has been attempted to improve the oil or fat functionalities and thus optimize their application in food products. Of the modification techniques in use direct blending of oil or fats is the method of choice as it is considered to be a cheap and non-destructive technique. The technique has been used to modify the suitability of several underutilized fats and oils [10]. There are basically three parameters in consideration to adjudge any oil as the healthy cooking oil: the ratio of saturated / monounsaturated / polyunsaturated fatty acid, ratio of essential fatty acids (Omega 6 / Omega 3fatty acids) and presence of natural antioxidants [11]. The oils can be blended to derive the protective advantage due to the presence of specific ingredients that offer protection against oxidation, to improve protection against oxidation and to improve stability during heating [12]. Several studies have been carried out on elucidating the physical and chemical properties of oil blends involving antioxidant properties of palm olein and palm oil which provide high levels of antioxidants. Because palm olein is stable on its own, when mixed with other oils, it actually increases the stability of the blend [13]. Palm olein is considered to be important edible oil due to the presence of high nutritionally and medicinally important minor constituents such as tocopherol, tocotrienols and sterols, taking advantage of the fact that micronutrient levels are so high in palm olein. It was considered that the value of any other edible oil could be remarkably increased by addition of even small amounts of palm olein [14]. It is this characteristic of palm olein, coupled with its excellent properties that make it unique for blending with palm kernel oil. The aim of this study is to evaluate the performance of blends of palm olein and palm kernel oil and the effect of temperature and time using photometric method to obtain physically and chemically stable Palm olein-Palm kernel oil blend.

TABLE 1: RATIO OF OIL BLENDS

\begin{tabular}{cc}
\multicolumn{2}{c}{ TABLE 1: RATIO OF OIL BLENDS } \\
\hline Palm olein (POL) & Palm kernel oil (PKO) \\
\hline 100 & 0 \\
80 & 20 \\
60 & 40 \\
40 & 60 \\
20 & 80 \\
0 & 100 \\
\hline
\end{tabular}

\section{MATERIALS AND METHOD}

\section{A. Materials}

The oils used for these studies were refined, bleached and deodourized palm olein and crude palm kernel oil. Samples were obtained from PRESCO Nig, Plc. Benin- City, Nigeria. CDR palm oil tester and reagent were purchased from FOODLAB (Florence, Italy). Fatty acid methyl ester (FAME) standards were purchased from Sigma-Aldrich (UK).

\section{B. Blend preparation}

Palm olein and palm kernel oil were mixed in proportions ranging from $100 \%$ palm kernel oil to $100 \%$ palm olein considered as control. $80 \%$ palm kernel oil blended with $20 \%$ palm olein and $60 \%$ palm kernel oil blended with $40 \%$ palm olein. $80 \%$ palm olein blended with $20 \%$ palm kernel oil and $60 \%$ palm olein blended with $40 \%$ palm kernel oil (vol/vol). Four blends were prepared and heated at 100,150 and $200{ }^{\circ} \mathrm{C}$ respectively.

\section{Fatty acid composition}

Relative concentration of fatty acid (FA) from oil samples were measured as their corresponding methyl esters according to the method described in [15] with a minor modification. Eight drops $(\sim 50 \mu \mathrm{L}$ each $)$ of oil was taken into $15 \mathrm{~mL}$ test tube and 8 drops of $0.5 \mathrm{M}$ methanolic potassium hydroxide, $10 \mathrm{~mL}$ of heptane mixed gently and allowed to settle for some time. The distinct upper layer of methyl ester in heptane was separated carefully in a capped vial from series of screw capped test tubes. The fatty acid was analyzed using an Agilent 6890 series gas chromatograph equipped with aliquots of $1 \mu \mathrm{L}$ inj (100:1 split). FAME was injected into GC-MS Agilent 5973 network-mass selective detector (Agilent technology- 7683 series). Auto sampler, - GC system, was used with the injection temperature maintained at $230{ }^{\circ} \mathrm{C}$ and $250{ }^{\circ} \mathrm{C}$, respectively. The carrier gas was helium $(1 \mathrm{ml} / \mathrm{min})$. The percentage was recorded with a standard chemstation data system. The MS library search report data/ NIST02.L Int was used to identify the various peaks.

\section{Determination of free fatty acids}

This method was carried out using CDR Palm oil Tester. Thirty numbers of test cuvettes were prepared prior to analysis. Exactly $1 \mathrm{~mL}$ of free fatty acid reagent was dispensed into each cuvette and closed with its supplied cap. The filled test cuvettes were incubated in the incubation cells of palm oil tester for 5 minutes. The incubated cuvettes were inverted to mix before inserting it in the reading cell. This was done to read the blank value of all filled cuvettes. At the end of the blank reading, to the same cuvette $5 \mu \mathrm{L}$ of each melted oil samples were added to the reagent. Immediately after adding, the cuvettes were inverted in order for the reagent to mix properly with the sample. The cuvette was inserted in the reading cell and the enter key was pressed. This was repeated for subsequent samples. At the end of the analysis, results were expressed in percentages, displayed and printed out.

\section{E. Determination of Peroxide Value}

The samples were determined as described by CDR Palm oil Tester. Thirty numbers of test cuvettes were prepared prior to analysis. Exactly $1 \mathrm{~mL}$ of peroxide value reagent was dispensed into each cuvette and closed with its supplied cap. The filled test cuvettes were incubated for 5 minutes. The incubated cuvettes were inverted to allow for mixing before inserting them in the reading cell. This was done to read the blank value of all filled cuvettes. After the blank reading, to the same cuvette, $5 \mu \mathrm{L}$ of each melted oil sample was added to the reagent. Immediately after adding, the cuvette was inverted, in order for the reagent to mix properly with the sample and repeated for subsequent samples. The cuvette was 
inserted in the reading cell. This was repeated for subsequent samples. At the end of the analysis, results were displayed and printed out.

\section{$F$. Determination of $P$-anisidine value}

This method was evaluated according to the method of CDR Palm oil Tester. Thirty number of test cuvettes were prepared prior to analysis. Exactly $1 \mathrm{~mL}$ of reagent was dispensed into each cuvette and closed with its supplied cap. The filled cuvette was incubated in the incubation cells for 5 minutes. The cuvette was then inserted in the reading cell. This was done to read the blank value of all filled cuvette at the end of the blank reading. The cap of the incubated cuvette was removed, and care was taken not to mix up the caps. Melted oil $(20 \mu \mathrm{L})$ samples were added to the cuvette and mixed properly. The cuvette was inserted into the reading cell to initiate the sample reading. At the end of the reading, the results were printed out automatically.

\section{G. Determination of Iodine Value}

This method was carried out using CDR Palm Oil Tester. Thirty number of test cuvettes were prepared prior to analysis. Exactly $1 \mathrm{~mL}$ of reagent was dispensed into each cuvette and closed with its supplied cap. The filled cuvette was incubated in the incubation cells for 5minutes. The cuvette was then inserted in the reading cell. This was done to read the blank value of all filled cuvettes. At the end of the blank reading, the caps of the incubated cuvettes were removed, and care was taken not to mix up the caps. The melted oil $20 \mu \mathrm{L}$ was added to the cuvette and mixed thoroughly. The cuvette was immediately inserted into the reading cell to initiate the sample reading. At the end of the reading, the result was printed out automatically.

\section{H. Determination of colour}

Colour was determined using [16] Lovibond Tintometer PFX995/Series, U12.5series. Cuvette cell path length was 5.25. The colour of the oil was compared with a trichloromatic system of filters and expressed in colours (red, yellow and green). This was used to estimate colour changes during heating. The colours were expressed in Lovibond RYB colour units. Each measurement was done in triplicate (16).

\section{Melting point}

Melting point was determined using the method of [16]. The solidified samples were completely melted at $60{ }^{\circ} \mathrm{C}$ before proceeding with the determination. The already melted samples were filtered through filter paper Whatman no. $41 \mathrm{H}$ to remove any impurities. Three clean capillary tubes were dipped into the oil samples. The sample rose to about $10 \mathrm{~mm}$ high in the tubes. The samples were chilled by holding the ends of the tubes that contained the sample against a piece of ice until the fat solidified. The tubes were placed in the beaker and in a refrigerator at $4-10{ }^{\circ} \mathrm{C}$ for $16 \mathrm{hrs}$. The tubes were removed from the refrigerator and the thermometer was attached with a rubber band to the tubes (multi-thermometer Eurolab ST9269B $-500^{\circ} \mathrm{C}$ to $+300{ }^{\circ} \mathrm{C}$ ) so that the lower ends of the thermometer were even with the melting point tubes and bottom of the mercury bulb of the thermometer. The thermometer was suspended in a $400 \mathrm{~mL}$ of clear distilled water. The bottom of the thermometer was immersed in the water to the immersion mark.

The starting bath temperature was adjusted to $8-10{ }^{\circ} \mathrm{C}$ below the slip point of the sample. The heating source SI Analytics was agitated with a small stream of air and heat was applied to the bath at the rate of $1^{\circ} \mathrm{C} / \mathrm{min}$, slowing the rate to $0.5{ }^{\circ} \mathrm{C} / \mathrm{min}$ as the slip point was approached. There was continuous heating until the fat column rose in each tube. The temperature at which each column rose was observed, and the average temperature of all tubes calculated. This was reported as slip melting point [17].

\section{J. Determination of cloud point}

Cloud point determination was carried out using [16]. The oil samples were heated to $130{ }^{\circ} \mathrm{C}$ for 5 minutes and $45 \mathrm{~mL}$ of the heated oil was poured into a $100 \mathrm{~mL}$ beaker. The beaker was placed in an ice bath. There was constant stirring with thermometer (multi thermometer Eurolab ST9269B $+300{ }^{\circ} \mathrm{C}$ to $-50{ }^{\circ} \mathrm{C}$ ) to keep the temperature uniform. From time to time, the beaker was removed, and the sample was inspected regularly for clouding. Reading was taken when the portion of thermometer immersed in the oil was no longer visible when viewed horizontally through the beaker.

\section{K. Viscosity}

This was done using Ostwald viscometer. The flow time of the oil samples were recorded with a stopwatch. It was calculated using the equation below.

$$
\mathrm{N}=\mathrm{mt}(\mathrm{nr} / \mathrm{mrtr})
$$

where $\mathrm{nr}$ is viscosity coefficient of the reference sample (water), $\mathrm{mr}$ is the mass of reference sample and tr is the time flow of the reference sample, $\mathrm{mt}$ is the flow time of the oil.

\section{Totox value}

The P-AnV is often used in the industry in conjunction with PV to calculate the so-called total oxidation or Totox value. The Totox value was calculated as:

$$
\text { Totox value }=2 \mathrm{PV}+\mathrm{PAnV}
$$

\section{Statistical Analyses}

All measurements were carried out in duplicate and reported as means $\pm \mathrm{SD}$ of dependent trials.

\section{RESUlt AND DISCUSSION}

\section{A. Fatty Acid Composition}

Fatty acid composition is one of the direct ways to predict the stability of the oils.

The fatty acid compositions of palm olein, palm kernel oils and their blends are presented in Tables 2-5. The Tables also depict the corresponding percentage saturated and unsaturated fatty acids. In The unheated palm olein (POL), the dominant fatty acids were 9- octadecenoic acid and pentadecanoic acid. In the unheated palm kernel oil (PKO), the dominant fatty acid was dodecanoic acid and 9octadecenoic acid. When unheated palm olein was heated the dominant fatty acid remained 9-octadecenoic acid and the oil 
remained largely unsaturated throughout the heating period. When untreated palm kernel oil was heated for varying temperature- time periods of 100,150 and $200{ }^{\circ} \mathrm{C}$ at 20,40 and 60 mins the dominant fatty acids were dodecanoic acid and methyl tetradecanoate acid. From the fatty acid profiles observed in Table 2-5, the oils can be classified as 9octadecenoic oils for palm olein, while palm kernel oil can be classified as dodecanoic acid. Tables 2-5 also depict the major fatty acid compositions of the oil blends. Blending palm olein with palm kernel oil altered the fatty acid composition of the native individual oils. Blending palm olein with palm kernel oil in different ratios revealed that as the proportion of palm kernel oil was increased, the relative concentration of the saturated fatty acids also increased while unsaturated fatty acids decreased in all the oils, as can be observed in Tables 2-5. Saturated fatty acids were the major fatty acids in all the blends of palm olein and palm kernel oil. The blending of palm olein with palm kernel oil (60:40) revealed that at the end of the heating period at $200{ }^{\circ} \mathrm{C}$ for $60 \mathrm{mins}$, the percentage 9-octadecenoic acid was 31.74 followed by Hexadecanoic acid $(28.92 \%)$ and dodecanoic acid $18.63 \%$. When higher quantity of palm olein was blended with palm kernel oil $(80: 20)$ at $200{ }^{\circ} \mathrm{C}$ for $60 \mathrm{mins}$, dodecanoic acid was greatly reduced because of reduced levels of palm kernel oil which is dodecanoic acid oils. This predictably increased the liquidity of the oil. This is an advantage with respect to its use as cooking oil. In order to increase the liquidity of oils, [18] suggested it would be achieved by increasing the percentage of 9- octadecenoic acid, while decreasing Hexadecanoic acid and dodecanoic acid. Blending palm kernel oil with palm olein (80:20) at various temperature and time resulted expectedly in dodecanoic acid being the major fatty acid followed by 9 octadecenoic acid > Hexadecanoic acid > methyl tetradecanoate acids.

Blends of palm kernel oil and palm olein $(60: 40)$ at temperature of 100,150 and time of $20,40,60$ mins on the other hand, resulted in 9- octadecenoic acid being the major fatty acid. In other words, although palm kernel oil was higher in the blend, 9- octadecenoic acid acid was the dominant fatty acid followed by dodecanoic $>$ Hexadecanoic $>$ methyl tetradecanoate acids. However, at $200{ }^{\circ} \mathrm{C}$ dodecanoic acid was the major fatty acid followed by 9 octadecenoic acid, at the end of heating, the percentage dodecanoic acid content was 27.51 from initial $27.16 \%$ and 9- octadecenoic acid decreased to 27.10 from initial $28.86 \%$ of the total fatty acids, thereby making dodecanoic acid the major fatty acid of blends of PKO: POL (60:40) heated at $200{ }^{\circ} \mathrm{C}$. Therefore, heating increased the degree of saturation of the blends. Saturation and unsaturation in oils and fats are associated with both desirable and undesirable implications depending on the food products in question. In margarine manufacture, high level of saturation of the raw oil material reduces the level of hydrogenation the oil must be subjected to, in order to achieve the desired product plasticity. A high level of saturation also reduces oxidative tendency in stored oils and therefore reduces the levels of synthetic antioxidants such as BHA, BHT, TBHQ, PG, needed to improve product shelf -life. However, oils and fats that are rich in saturated fatty acids are less fluid at ambient conditions and less heart friendly being associated with health conditions such as coronary thromobsis and atherosclerosis. Accordingly, the results presented in these Tables 2-5 of fatty acid profiles should be viewed within these contexts. In accordance with the results presented in these studies, prolonged heating generally decreased oleic acid content of the samples. The increases and decreases in the fatty acid content could result in changes in physicochemical and functional properties of the blends. The results indicate that the thermal stability of the oil samples was dependent on the fatty acid composition of the oil samples. Oils with more unsaturated fatty acids produce more volatile compounds than the saturated ones, which are generally more stable to oxidation and less sensitive to thermal stress.

TABLE 2: PERCENTAGE FATTY ACID COMPOSITION OF PALM OLEIN AND
PALM KERNEL OIL UNHEATED (AS CONTROL)

\section{A. Free Fatty Acid}

The heated palm kernel oil shows a gradual increase initially in free fatty acid content for all the oil samples. As the amount of PKO increase in the blends and was heated there was reduction in the free fatty acid as temperature and time increased initially, at higher temperature there was reduction. There was increase in the amount of FFA as POL was heated, higher blends of palm olein also showed increase in FFA heated at $100^{\circ} \mathrm{C}$ there was reduction in the free fatty acid as the temperature increased. This may be as a result of most of the free fatty acids escaping as volatiles as temperature was increased. Hydrolysis of triglycerides is a factor in the formation of free fatty acids in oils. This is capable of producing compounds susceptible to oxidative reactions [19]. The free fatty acid content of untreated palm kernel oil was within the PORIM standard of 5.0\%. However, the free fatty acid value for the heated palm olein of $0.11 \%$ was slightly higher than the PORIM standard of $0.10 \%$. [20] Reported a similar low free fatty acid content of $0.10 \%$ at the onset of heating for typical palm olein. When heated, free fatty acid content was higher in sunflower oil when compared 
to special quality olein and palm olein. He reported that after 16 hours of heating, a free fatty acid content of $0.14 \%$ was observed for palm olein. [21] also reported that superior quality palm olein exhibited the lowest free fatty acid content of $0.18 \%$ from an initial $0.05 \%$ compared to standard palm olein $(0.25 \%)$ after frying for 5 days at 12 hours per day. Observed increases in the percentage free fatty acid contents of the oils could have been due to water -induced hydrolysis of the ester bonds in the triacylglycerols. Additionally, lipolytic activity of contaminating microorganism could also affect ester bonds and increase percentage free fatty acid values. The free fatty acid level is a measurement of hydrolytic rancidity, caused by a combination of enzymes and moisture. This is a problem mainly encountered in products based on dodecanoic acid oils, such as coconut and palm kernel oil. The FFAs are liberated from the parent oils, which comprise large amounts of decanoic acid, dodecanoic acid and methyl tetradecanoate acids. These acids have a distinct soapy flavor and have lower flavor threshold values than the longer chain fatty acids found in other oils and fats [22].

Lipase is a type of enzyme responsible for catalysing the hydrolysis of triglycerides into fatty acid and glycerol Triglycerides are the most common types of lipids, which consist of one glycerol molecule and three fatty acid molecules bond together by ester bonds. When this bond is broken by microbes there is increase in FFA. Refining, generally, eliminates microbial contaminants which can raise percentage free fatty acid values of oil samples. Furthermore, elevated temperatures may induce thermo- catalysed breakdown of ester bonds in the triacyglycerols of the oil samples. Accordingly, the changes in the percentage free fatty acid contents of the oil samples reported in Table 6 could have resulted from the interplay of factors such as water induced reactions, enzyme induced lipolysis and thermocatalysis.

TABLE 3: PERCENTAGE FATTY ACID PROFILES OF PALM OLEIN, PALM KERNEL OIL AND THEIR BLENDS HEATED AT $100{ }^{\circ} \mathrm{C}$

\begin{tabular}{|c|c|c|c|c|c|c|c|c|c|c|c|c|c|c|}
\hline \multicolumn{2}{|c|}{ Fatty acid composition (\%) } & \multicolumn{4}{|c|}{ POL heated at $100^{\circ} \mathrm{C}$} & \multicolumn{3}{|c|}{ PKO heated at $100^{\circ} \mathrm{C}$} & \multicolumn{3}{|c|}{ PKO:POL (80:20) } & \multicolumn{3}{|c|}{ PKO:POL (60:40) } \\
\hline \multicolumn{2}{|c|}{ Mins } & 20 & & 40 & & & 40 & 60 & 20 & 40 & 60 & 20 & 40 & 60 \\
\hline \multicolumn{2}{|l|}{ Hexanoic acid } & - & & - & & & - & - & 0.15 & - & - & - & - & - \\
\hline \multicolumn{2}{|l|}{ Octanoic acid } & - & & .11 & & & 2.8 & 3.05 & 2.48 & 2.29 & 2.63 & 1.86 & 1.93 & 1.87 \\
\hline \multicolumn{2}{|l|}{ Dodecanoic acid } & 1.02 & & .79 & 0. & & 44.6 & 44.81 & 35.63 & 39.11 & 38.81 & 26.90 & 27.02 & 27.16 \\
\hline \multicolumn{2}{|l|}{ Methyl tetradecanoate } & 0.91 & & .19 & 0. & & 17.2 & 17.44 & 13.44 & 12.69 & 14.06 & 10.22 & 10.28 & 10.25 \\
\hline \multicolumn{2}{|l|}{ Pentadecanoic acid } & 36.56 & & - & 37 & & 9.47 & - & - & 14.96 & 15.39 & - & - & - \\
\hline \multicolumn{2}{|l|}{ Oxacyclohexadecan-2-one } & 0.12 & & - & & & - & - & - & - & - & - & - & - \\
\hline \multicolumn{2}{|l|}{ 7-Hexadecenoic acid } & 0.23 & & - & & & - & - & - & - & - & - & - & - \\
\hline \multicolumn{2}{|l|}{ Heptadecanoic acid } & 0.08 & & - & 0. & & - & - & - & - & - & 0.21 & 3.65 & - \\
\hline \multicolumn{2}{|l|}{ Hexadecanoic acid } & - & & 5.69 & & & - & 9.24 & 15.15 & - & - & 20.77 & 20.88 & 20.99 \\
\hline \multicolumn{2}{|l|}{ Tridecanoic acid } & - & & - & & & - & - & 0.06 & - & - & - & - & - \\
\hline \multicolumn{2}{|l|}{ Cyclohexanone } & - & & 0.0 & & & - & - & - & - & - & - & - & - \\
\hline \multicolumn{2}{|l|}{ 9-Hexadecenoic acid } & - & & .19 & 0. & & - & - & - & - & - & - & - & - \\
\hline \multicolumn{2}{|l|}{ Octadecanoic acid } & 5.39 & & .26 & 5. & & 2.7 & 2.75 & 3.23 & 2.97 & 3.17 & 3.74 & - & 3.71 \\
\hline 8-Octadecenoic acid & & - & & 5.49 & & & 17.0 & - & - & - & - & - & 29.12 & - \\
\hline 9,12 - Octadecadienoic ac & & 8.56 & & - & & & 2.6 & 2.61 & 3.94 & - & 3.84 & 5.10 & - & - \\
\hline 10,13-Octadecadienoic a & & - & & .29 & & & - & - & - & 3.62 & - & - & - & - \\
\hline $9,12,15$ Octadecatrienoic & & 0.19 & & .18 & 0. & & - & - & - & & & & & \\
\hline Eicosenoic acid & & 0.38 & & .37 & 0. & & 0.12 & 0.09 & 0.15 & & 0.18 & & & 0.21 \\
\hline 11- Eicosenoic acid & & 0.16 & & .16 & 0. & & - & - & 0.11 & & & 0.12 & 0.19 & 0.11 \\
\hline $\begin{array}{l}\text { Fatty acid composition } \\
\qquad(\%)\end{array}$ & POL:P & PKO (8 & 20) & at 100 & & POL:P & $(60: 40)$ & $100^{\circ} \mathrm{C}$ & POL & eated at 1 & ${ }^{\circ} \mathrm{C}$ & $\mathrm{PKC}$ & neated at & $150{ }^{\circ} \mathrm{C}$ \\
\hline Mins & 20 & & & 6 & & 20 & 40 & 60 & 20 & 40 & 60 & 20 & 40 & 60 \\
\hline Octanoic acid & 0.52 & & & 0. & & 1.18 & 1.15 & 1.17 & - & - & - & 2.98 & 2.94 & 3.01 \\
\hline Decanoic acid & 0.47 & & & 0. & & 1.09 & 1.06 & 1.09 & - & - & - & 2.95 & 2.90 & 2.95 \\
\hline Dodecanoic acid & 8.33 & & & 7. & & 17.79 & 17.01 & 17.78 & 0.21 & 0.21 & 0.19 & 44.87 & 43.56 & 45.41 \\
\hline Methyl tetradecanoate & 3.39 & & & 3. & & 6.89 & 6.65 & 6.83 & 0.59 & 0.62 & 0.64 & 17.28 & 16.79 & 17.42 \\
\hline Pentadecanoic acid & - & & & 33 & & 26.88 & 25.94 & - & - & - & - & - & 10.28 & 9.12 \\
\hline $\begin{array}{l}\text { Oxacyclohexadecan-2- } \\
\text { one }\end{array}$ & - & & & & & 0.10 & - & - & - & - & - & - & - & - \\
\hline 7-Hexadecenoic acid & - & & & & & - & - & - & 0.20 & - & - & - & - & - \\
\hline Heptadecanoic acidne & 0.07 & & & 0. & & - & - & - & - & - & 0.08 & - & - & - \\
\hline Hexadecanoic acid & 33.30 & & & & & - & - & 26.81 & 37.93 & 37.91 & 37.35 & 9.14 & - & - \\
\hline 9-Hexadecenoic acid & - & & & & & - & - & 0.10 & - & - & - & - & - & - \\
\hline 11-Hexadecenoic acid & 0.15 & & & - & & - & 0.09 & - & - & 0.21 & 0.15 & - & - & - \\
\hline $\begin{array}{l}7,10,13- \\
\text { Hexadecatrienoic acid }\end{array}$ & - & & & . & & - & - & 0.11 & - & - & - & - & - & - \\
\hline Octadecanoic acid & 4.78 & & & 5. & & 4.24 & 4.18 & 4.37 & 5.23 & 5.34 & 5.48 & 2.75 & 2.85 & 2.69 \\
\hline 8-Octadecenoic acid & - & & & - & & - & - & - & - & - & - & 17.25 & - & - \\
\hline 9- Octadecenoic acid & 40.46 & & & 40 & & 34.97 & 33.99 & 34.91 & 46.51 & 46.27 & 46.60 & - & 17.72 & 16.85 \\
\hline $\begin{array}{l}\text { 11,14-Octadecadienoic } \\
\text { acid }\end{array}$ & - & & & - & & - & - & - & - & 0.20 & - & - & - & - \\
\hline $\begin{array}{l}8,11 \text { - Octadecadienoic } \\
\text { acid }\end{array}$ & 7.71 & & & . & & - & - & - & 8.41 & 8.52 & - & - & 2.83 & - \\
\hline
\end{tabular}




\begin{tabular}{|c|c|c|c|c|c|c|c|c|c|c|c|c|}
\hline $\begin{array}{l}3,14,16- \\
\text { Nonadecatetrae }\end{array}$ & - & 0.08 & - & - & - & - & - & - & - & - & - & - \\
\hline $\begin{array}{l}\text { 9,12- Octadecadienoic } \\
\text { acid }\end{array}$ & - & - & 7.91 & 6.30 & 6.23 & 6.31 & - & - & 8.75 & - & - & - \\
\hline $\begin{array}{l}\text { 10,13-Octadecadienoic } \\
\text { acid }\end{array}$ & - & - & - & - & - & - & 0.18 & - & - & 2.63 & - & - \\
\hline $\begin{array}{l}9,12,15- \\
\text { Octadecatrienoic acid }\end{array}$ & 0.81 & 0.19 & 0.19 & 0.13 & 0.12 & & 0.19 & 0.21 & 0.19 & - & - & - \\
\hline $\begin{array}{l}9,22 \text { - Octadecadienoic } \\
\text { acid }\end{array}$ & - & - & - & - & - & - & - & - & - & - & - & 2.54 \\
\hline Eicosenoic acid & 0.29 & 0.12 & 0.36 & 0.27 & 0.26 & 0.29 & 0.37 & 0.36 & - & - & 0.13 & - \\
\hline 11- Eicosenoic acid & - & - & 0.16 & 0.14 & 0.13 & 0.15 & 0.17 & 0.15 & 0.17 & - & - & - \\
\hline $\begin{array}{l}\text { Cyclopropaneoctanoic } \\
\text { acid }\end{array}$ & - & 0.06 & - & - & - & - & - & - & - & - & - & - \\
\hline 15-tetracosenoic acid & - & 0.15 & - & - & - & - & - & - & - & - & - & - \\
\hline Tetracosanoic acid & - & - & 0.02 & - & - & - & - & - & - & - & - & - \\
\hline Docosanoic acid & - & 0.03 & 0.03 & - & - & - & - & - & - & - & - & - \\
\hline
\end{tabular}

TABLE 4: PERCENTAGE FATTY ACID PROFILES OF PALM OLEIN, PALM KERNEL OIL AND THEIR BLENDS HEATED AT $150{ }^{\circ} \mathrm{C}$

\begin{tabular}{|c|c|c|c|c|c|c|c|c|c|c|c|c|}
\hline \multirow{2}{*}{$\begin{array}{l}\text { Fatty acid composition } \\
(\%)\end{array}$} & \multicolumn{3}{|c|}{ PKO:POL (80:20) } & \multicolumn{3}{|c|}{ PKO:POL (60:40) } & \multicolumn{3}{|c|}{ POL:PKO (60:40) } & \multicolumn{3}{|c|}{ POL:PKO (80.20) } \\
\hline & 20 & 40 & 60 & 20 & 40 & 60 & 20 & 40 & 60 & 20 & 40 & 60 \\
\hline Octanoic acid & 2.69 & 2.49 & 2.31 & 1.87 & 1.91 & 1.90 & 1.16 & 1.23 & 1.19 & 0.59 & 0.54 & 0.59 \\
\hline Decanoic acid & 2.63 & 2.39 & 2.16 & 1.76 & 1.81 & 1.79 & 1.11 & 1.15 & 1.12 & & 0.51 & 0.53 \\
\hline Dodecanoic acid & 39.11 & 36.42 & 30.76 & 26.74 & 27.79 & 27.41 & 17.72 & 18.16 & 17.73 & 0.09 & 8.32 & 0.59 \\
\hline Undecanoic acid & - & - & - & - & - & - & - & - & - & 0.53 & - & - \\
\hline Methyl tetradecanoate & 13.78 & 13.69 & 12.69 & 10.07 & 10.46 & 10.19 & 6.88 & 7.09 & 6.87 & 3.49 & 3.24 & 3.49 \\
\hline Pentadecanoic acid & - & - & 18.32 & 21.02 & - & - & 26.83 & - & - & - & - & - \\
\hline Cyclopentadecanone & - & - & - & - & - & - & - & 0.14 & - & - & - & - \\
\hline Heptadecanoic acid & - & - & - & - & - & - & - & - & - & 0.07 & 0.07 & 0.07 \\
\hline Hexadecanoic acid & 14.51 & 15.15 & 0.16 & - & 21.59 & 20.85 & - & 26.56 & 26.79 & 34.74 & 33.45 & 34.74 \\
\hline 11-Hexadecenoic acid & - & - & - & - & - & - & - & 0.16 & - & 0.17 & 0.24 & 0.17 \\
\hline Tetradecanoic acid & - & - & - & - & - & - & - & - & 0.09 & - & - & - \\
\hline 9-Hexadecenoic acid & - & - & - & - & - & - & - & - & 0.13 & - & - & - \\
\hline Octadecanoic acid & 2.87 & 3.19 & 3.42 & 3.71 & 3.79 & 3.63 & 4.31 & 4.36 & 4.34 & 4.66 & 4.63 & 4.66 \\
\hline 9- Octadecenoic acid & 20.91 & 22.81 & 25.96 & 29.38 & 27.26 & 28.64 & 34.93 & 34.37 & 34.78 & 38.56 & 39.97 & 38.56 \\
\hline $\begin{array}{l}\text { 9,12- Octadecadienoic } \\
\text { acid }\end{array}$ & - & - & 4.21 & - & - & - & 6.16 & - & 6.08 & - & 7.33 & - \\
\hline $\begin{array}{l}9,12,15 \text { Octadecatrienoic } \\
\text { acid }\end{array}$ & - & - & - & - & - & - & 9.45 & 0.13 & 0.10 & 0.19 & 0.17 & 0.19 \\
\hline Eicosenoic acid & - & 0.13 & - & 0.21 & 0.19 & 0.20 & 0.30 & 0.29 & 0.28 & 0.28 & 0.29 & 0.28 \\
\hline 11- Eicosenoic acid & - & - & - & 0.12 & - & 0.11 & 0.15 & - & 0.16 & 0.14 & 0.13 & 0.14 \\
\hline
\end{tabular}

TABLE 5: PERCENTAGE FATTY ACID PROFILES OF PALM OLEIN, PALM KERNEL OIL AND THEIR BLENDS HEATED AT $200^{\circ} \mathrm{C}$

\begin{tabular}{|c|c|c|c|c|c|c|c|c|c|c|c|c|}
\hline \multirow{2}{*}{$\begin{array}{l}\text { Fatty acid composition }(\%) \\
\text { Mins }\end{array}$} & \multicolumn{3}{|c|}{ PKO:POL (80:20) } & \multicolumn{3}{|c|}{ PKO:POL (60:40) } & \multicolumn{3}{|c|}{ POL:PKO (60:40) } & \multicolumn{3}{|c|}{ POL:PKO (80.20) } \\
\hline & 20 & 40 & $60 *$ & 20 & 40 & 60 & 20 & 40 & 60 & 20 & 40 & 60 \\
\hline Octanoic acid & 2.54 & 2.61 & 2.63 & 1.99 & 1.95 & 1.97 & 1.20 & 1.24 & 1.33 & 0.52 & 0.57 & 0.55 \\
\hline Decanoic acid & 2.33 & 2.45 & 2.45 & 1.88 & 1.81 & 1.83 & 1.11 & 1.19 & 1.18 & 0.45 & 0.51 & 0.49 \\
\hline Dodecanoic acid & 37.00 & 38.18 & 38.15 & 28.14 & 27.49 & 27.51 & 17.90 & 17.91 & 18.63 & 7.76 & 8.68 & 7.58 \\
\hline Methyl tetradecanoate & 13.89 & 14.01 & 14.29 & 10.75 & 10.50 & 10.55 & 6.98 & 6.90 & 7.22 & 3.25 & 3.45 & 3.21 \\
\hline Pentadecanoic acid & - & - & 15.87 & - & - & - & - & - & - & 33.28 & 0.03 & - \\
\hline Cyclopropanenonanoic acid & - & - & - & - & - & - & - & - & - & - & 0.04 & - \\
\hline 7-Hexadecenoic acid & - & - & - & - & - & - & - & 0.11 & - & - & - & - \\
\hline Heptadecanoic acid & & & & & & & & & & 0.08 & 0.07 & 0.08 \\
\hline Hexadecanoic acid & - & 15.53 & - & 21.99 & 21.48 & 22.13 & 27.06 & 27.66 & 28.92 & 0.11 & 34.22 & 34.56 \\
\hline 11-Hexadecenoic acid & - & - & - & - & - & - & 0.13 & - & - & - & 0.25 & 0.17 \\
\hline Nonanoic acid & - & - & - & - & - & - & - & - & - & - & - & 0.05 \\
\hline 9-Hexadecenoic acid & - & - & - & - & - & - & - & - & 0.11 & 0.19 & - & - \\
\hline Octadecanoic acid & 15.29 & 3.10 & 3.03 & 3.93 & 3.79 & 3.93 & 4.42 & 4.48 & 4.64 & 4.94 & - & 5.00 \\
\hline 8-Octadecenoic acid & 22.46 & - & 20.99 & & & & & & & & 38.48 & \\
\hline 9- Octadecenoic acid & - & 21.58 & - & 27.59 & 28.32 & 27.10 & 34.61 & 33.91 & 31.74 & 41.15 & - & 40.43 \\
\hline 8,11 - Octadecadienoic acid & 3.16 & 2.53 & 1.76 & 4.82 & - & - & 5.75 & - & - & 7.19 & - & 5.90 \\
\hline 9,12- Octadecadienoic acid & - & - & - & - & - & 2.84 & - & 5.05 & - & - & 6.69 & - \\
\hline 10,13-Octadecadienoic acid & - & - & - & - & 3.87 & - & - & - & - & - & - & - \\
\hline $9,12,15$ Octadecatrienoic acid & - & - & - & - & - & - & 0.12 & - & - & 0.15 & 0.18 & 0.10 \\
\hline 9,22 -Octadecadienoic acid & - & - & - & - & - & - & - & - & 4.22 & - & - & - \\
\hline Oxiraneoctanoic acid & - & - & - & - & 0.08 & 0.41 & - & 0.17 & 0.32 & - & - & - \\
\hline Eicosenoic acid & 0.14 & - & 0.16 & 0.24 & 0.23 & 0.25 & 0.30 & 0.31 & 0.32 & 0.15 & 0.32 & 0.34 \\
\hline 11- Eicosenoic acid & - & - & - & 0.14 & 0.12 & 0.11 & 0.15 & 0.41 & 0.15 & 0.15 & 0.18 & 0.14 \\
\hline Docosanoic acid & - & - & - & - & - & - & - & - & - & 0.04 & 0.05 & - \\
\hline Tetracosanoic acid & - & - & - & - & - & - & - & - & - & 0.04 & 0.03 & 0.06 \\
\hline
\end{tabular}


TABLE 6: EFFECT OF HEATING PALM OLEIN, PALM KERNEL OIL AND THEIR BLENDS ON FREE FATTY ACID VALUES

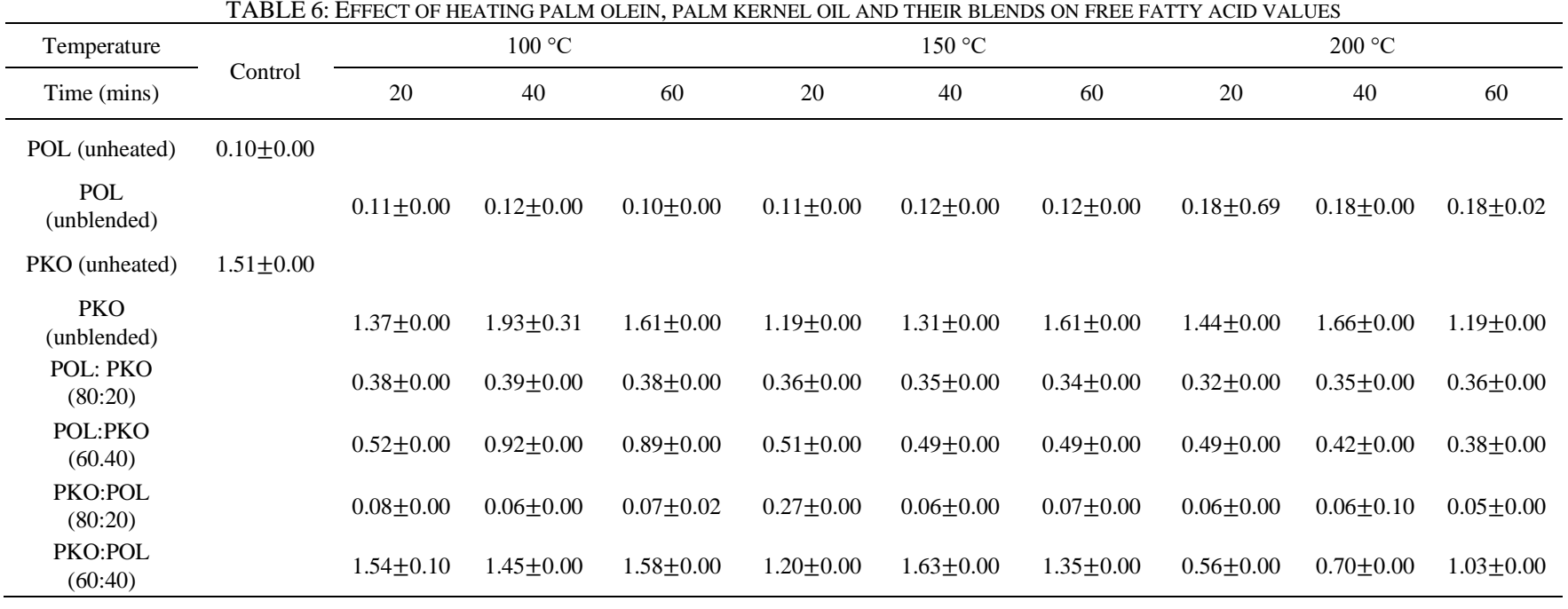

\section{B. Iodine Value}

Iodine value measures the degree of unsaturation of oils and fats as determined by various standard methods such as the Wijs [23]. Table 6 shows the iodine values of palm olein, palm kernel oil and their blends. The iodine value of untreated palm olein was $52.37 \mathrm{~g} / 100 \mathrm{~g}$ and Palm kernel oil was $13.08 \mathrm{~g} / 100 \mathrm{~g}$. When palm olein and palm kernel oil were heated, results in Table 6 suggest that palm olein were more vulnerable to oxidation at the onset of heating, but as heating progressed there was reduction in the iodine values of palm olein at $200{ }^{\circ} \mathrm{C}$ for 40 and 60 mins there was slight reduction in that of PKO. The observed decreases in iodine value of palm oleins indicate loss of unsaturation as a result of the heat treatment and may be attributed to oxidation at elevated temperatures. The oxidation of double bonds in fatty acids by thermal stress and polymerisation of molecules of unsaturated fatty acids would lead to decrease in the degree of unsaturation and therefore, decreased iodine value also. Palm kernel oil and its blend of (60:40) was apparently more stable during heating since at high temperature the palm kernel oil showed no loss in iodine value probably because of the presence of mainly saturated fatty acids which can be seen in Table 3-5. Table 3-5 which depicts the fatty acid composition of the oil samples employed in the test shows that palm olein had $46.18 \%$ total unsaturated fatty acids. The use of fats and oils with low unsaturation in processing is advisable because the oxidation rate of such oils is lower. Unsaturated fatty acids generally, are responsible for the oxidation and off-flavours development that lower the palatability of fried foods [24]-[25]. Palm kernel oil blends with palm olein showed significant improvement in aroma and taste at room temperature and the oil was free flowing and did not solidify. Therefore, it is recommended that palm kernel oil be blended because of the low iodine value which leads to great thermal resistance, less thermally induced oxidation and polymerisation. However, it should be noted that high levels of unsaturation in oils are better for the human body from the point of view of human nutrition. Coronary thrombosis, artherosclerosis are usually more associated with highly saturated oils and fats than with the highly unsaturated oils and fats.

\section{P-anisidine Value}

$\mathrm{P}$-anisidine value $(\mathrm{AnV})$ is used to monitor the degree of secondary oil oxidation during frying. This parameter determines the content of aldehydes in the oil samples when hydroperoxides, developed in the early stages of oxidation, decompose spontaneously when exposed to high heating temperatures [26]. Indeed, anisidine value is said to be a reliable index or parameter to express the oxidative state of oil samples as aldehyde, since anisidine has higher resistance to decomposition on heating when compared to hydroperoxide. The initial anisidine value in the oil samples were palm olein $1.30 \mathrm{~g} / \mathrm{mL}$ and palm kernel oil $1.00 \mathrm{~g} / \mathrm{mL}$ (Table 8). Palm olein being unsaturated the deterioration rate was faster at low temperatures of 100 and $150{ }^{\circ} \mathrm{C}$. The lower the anisidine value, the better the quality of the oil. The blends showed more deterioration at higher temperature. However, as heating increased up to $200{ }^{\circ} \mathrm{C}$, there were increases in p-AVs with palm kernel oil having the highest increase of $31.40 \mathrm{~g} / \mathrm{mL}$. The palm kernel oil decomposition rate was faster at high temperature. Increase in anisidine value obtained in this study at $200{ }^{\circ} \mathrm{C}$ for palm kernel oil would be due to advanced stages of secondary oxidation in which constituents such as carbonyls, alcohols and fatty acids have subsequently reacted with oxygen to generate higher molecular weight compounds by reactions between fatty acids e.g., carbon- to -carbon or oxygen to carbon bridges [27]. Breakdown of unsaturated fatty acids is reflected in changes in iodine value which is a measure of unsaturation in fatty acids. This suggests that fatty acid composition affected formation of secondary oxidation products from primary oxidation products in oil during heating. Iodine value of Table 6 and anisidine value of Table 8 shows that iodine value is inversely proportional to anisidine value. The decrease in iodine value in Table 7 corresponded to increase in anisidine value. Thus, anisidine value increased as aldehydes were produced in the oils and their blends at higher temperatures and longer duration of heating. 
TABLE 7: EFFECT OF HEATING PALM OLEIN, PALM KERNEL OIL AND THEIR BLENDS ON IODINE VALUE

\begin{tabular}{|c|c|c|c|c|c|c|c|c|c|c|}
\hline Temperature & \multirow{2}{*}{ Control } & \multicolumn{3}{|c|}{$100^{\circ} \mathrm{C}$} & \multicolumn{3}{|c|}{$150^{\circ} \mathrm{C}$} & \multicolumn{3}{|c|}{$200^{\circ} \mathrm{C}$} \\
\hline Time (mins) & & 20 & 40 & 60 & 20 & 40 & 60 & 20 & 40 & 60 \\
\hline POL untreated & $52.37 \pm 0.00$ & & & & & & & & & \\
\hline POL heated & & $\begin{array}{l}54.48 \\
\pm 0.01\end{array}$ & $54.65 \pm 0.48$ & $57.64 \pm 0.00$ & $52.19 \pm 0.01$ & $50.70 \pm 0.00$ & $42.31 \pm 0.01$ & $50.95 \pm 0.02$ & $56.68 \pm 0.00$ & $44.96 \pm 0.00$ \\
\hline PKO Untreated & $13.08 \pm 0.00$ & & & & & & & & & \\
\hline PKO heated & & $13.00 \pm 00$ & $13.00 \pm 00$ & $13.00 \pm 0.00$ & $14.34 \pm 0.00$ & $13.31 \pm 0.00$ & $13.71 \pm 0.00$ & $17.60 \pm 0.00$ & $12.00 \pm 0.00$ & $11.00 \pm 0.00$ \\
\hline PKO:POL(80:20) & & $16.81 \pm 1.37$ & $16.79 \pm 1.42$ & $18.18 \pm 0.95$ & $17.86 \pm 0.63$ & $19.05 \pm 0.09$ & $15.12 \pm 0.00$ & $18.00 \pm 0.00$ & $18.00 \pm 0.10$ & $15.01 \pm 0.00$ \\
\hline PKO:POL(60:40) & & $27.55 \pm 0.01$ & $28.68 \pm 0.00$ & $23.47 \pm 0.00$ & $28.18 \pm 0.10$ & $21.55 \pm 0.40$ & $32.48 \pm 0.01$ & $34.89 \pm 0.00$ & $26.59 \pm 0.00$ & $29.79 \pm 0.01$ \\
\hline $\begin{array}{c}\text { POL: PKO } \\
(80: 20)\end{array}$ & & $39.03 \pm 0.06$ & $40.03 \pm 0.06$ & $42.00 \pm 0.00$ & $43.10 \pm 0.10$ & $41.02 \pm 0.00$ & $41.00 \pm 0.00$ & $42.00 \pm 0.00$ & $39.00 \pm 0.00$ & $40.02 \pm 0.00$ \\
\hline $\begin{array}{c}\text { POL :PKO } \\
(60: 40)\end{array}$ & & $33.22 \pm 0.01$ & $37.58 \pm 0.01$ & $37.12 \pm 0.01$ & $33.48 \pm 0.01$ & $33.45 \pm 0.01$ & $31.82 \pm 0.00$ & $32.32 \pm 0.01$ & $29.45 \pm 0.01$ & $29.09 \pm 0.01$ \\
\hline
\end{tabular}

TABLE 8: EFFECT OF HEATING PALM OLEIN, PALM KERNEL OIL AND THEIR BLENDS ON P-AV (G/ML)

\begin{tabular}{|c|c|c|c|c|c|c|c|c|c|c|}
\hline \multirow{2}{*}{$\begin{array}{l}\text { Temperature } \\
\text { Time (mins) }\end{array}$} & \multirow{2}{*}{ Control } & \multicolumn{3}{|c|}{$100^{\circ} \mathrm{C}$} & \multicolumn{3}{|c|}{$150^{\circ} \mathrm{C}$} & \multicolumn{3}{|c|}{$200^{\circ} \mathrm{C}$} \\
\hline & & 20 & 40 & 60 & 20 & 40 & 60 & 20 & 40 & 60 \\
\hline POL untreated & $1.30 \pm 0.00$ & & & & & & & & & \\
\hline POL heated & & $1.60 \pm 0.00$ & $1.60 \pm 0.48$ & $1.40 \pm 0.22$ & $1.40 \pm 0.00$ & $1.50 \pm 0.00$ & $1.00 \pm 0.72$ & $1.80 \pm 0.00$ & $1.20 \pm 0.00$ & $2.70 \pm 0.00$ \\
\hline PKO Untreated & $1.00 \pm 0.00$ & & & & & & & & & \\
\hline PKO heated & & $1.10 \pm 0.01$ & $1.10 \pm 0.00$ & $1.00 \pm 0.00$ & $1.30 \pm 0.00$ & $1.11 \pm 0.00$ & $10.82 \pm 0.00$ & $17.20 \pm 0.00$ & $21.20 \pm 0.00$ & $31.40 \pm 0.00$ \\
\hline PKO:POL(80:20) & & $1.10 \pm 1.37$ & $1.00 \pm 0.00$ & $0.80 \pm 0.95$ & $1.00 \pm 0.63$ & $2.00 \pm 2.11$ & $3.10 \pm 0.00$ & $5.80 \pm 0.00$ & $7.20 \pm 0.00$ & $7.70 \pm 0.00$ \\
\hline PKO:POL $(60: 40)$ & & $0.90 \pm 1.00$ & $1.08 \pm 0.00$ & $1.00 \pm 0.00$ & $1.10 \pm 0.00$ & $1.10 \pm 0.00$ & $1.10 \pm 0.00$ & $2.60 \pm 0.00$ & $3.20 \pm 0.00$ & $2.50 \pm 0.00$ \\
\hline POL:PKO(60:40) & & $1.60 \pm 0.00$ & $1.20 \pm 0.00$ & $1.30 \pm 0.00$ & $2.70 \pm 0.0$ & $3.40 \pm 0.0$ & $3.10 \pm 0.00$ & $8.80 \pm 0.00$ & $5.60 \pm 0.00$ & $9.60 \pm 0.00$ \\
\hline
\end{tabular}

\section{Peroxide Values}

Table 9 shows the peroxide values (PV) of palm olein, palm kernel oil and their blends. Unheated palm olein (Table 9) had a peroxide value of $9.47 \mathrm{meq} / \mathrm{kg}$; this initial peroxide value of the sample exceeded the maximum allowable limit which is $2.0 \mathrm{meq} / \mathrm{kg}$ for palm olein [5]. When unblended palm olein (POL) was heated, its peroxide value increased reaching a maximum of $19.33 \mathrm{meq} / \mathrm{kg}$ at $150{ }^{\circ} \mathrm{C}$ for $60 \mathrm{mins}$. At $200{ }^{\circ} \mathrm{C}$ the PV decreased apparently because the peroxides became unstable and decomposed. An increase in peroxide value during the initial stage of heating at $100^{\circ} \mathrm{C}$ was followed by a decrease after further heating at $150{ }^{\circ} \mathrm{C}$ and $200^{\circ} \mathrm{C}$. This is apparently because peroxides being unstable at elevated temperatures tend to decompose to form secondary oxidation products such as aldehydes and ketones. The thermal instability of peroxides in palm olein may be related to its fatty acid composition and their degrees of unsaturation. Palm olein was therefore, unstable at these higher temperatures. A different pattern was observed, however, for palm kernel oil. When initially unheated PKO was heated, there was an initial reduction in peroxide value from 2.88 to $1.93 \mathrm{meq} / \mathrm{kg}$ but at higher temperatures of $150{ }^{\circ} \mathrm{C}$ and 200 ${ }^{\circ} \mathrm{C}$, an increase to $9.44 \mathrm{meq} / \mathrm{kg}$ occurred (Table 9). The peroxide values of the blends varied with the proportion of palm kernel oil in the blends. The blends with higher amounts of PKO (PKO: POL 80:20) were more stable throughout the heating period with initial value of $1.90 \mathrm{meq} / \mathrm{kg}$ to final value of $11.61 \mathrm{meq} / \mathrm{kg}$ with respect to peroxide value increasing gradually with temperature increase. The stability of palm kernel oil and palm olein blends was apparently due to the dominant saturated fatty acid, dodecanoic acid, in palm kernel oil contributing a higher amount of saturated fatty acid in the blends. Blends with higher palm olein (POL:PKO 80:20) than palm kernel oil contents showed increased peroxide values initially $11.48 \mathrm{meq} / \mathrm{kg}$, but had decreased peroxide values as the temperature increased to $7.12 \mathrm{meq} / \mathrm{kg}$, probably because of thermal decomposition of the peroxides (lower peroxides).

TABLE 9: EFFECTS OF HEATING PALM OLEIN, PALM KERNEL OIL AND THEIR BLENDS AT $100^{\circ} \mathrm{C}, 150{ }^{\circ} \mathrm{C}$ AND $200{ }^{\circ} \mathrm{C}$ ON THE PEROXIDE VALUES (MEQ/KG) OF THE OIL SAMPLES

\begin{tabular}{|c|c|c|c|c|c|c|c|c|c|c|}
\hline \multirow{2}{*}{$\frac{\text { Temperature }}{\text { Time (mins) }}$} & \multirow{2}{*}{ Control } & \multicolumn{3}{|c|}{$100^{\circ} \mathrm{C}$} & \multicolumn{3}{|c|}{$150^{\circ} \mathrm{C}$} & \multicolumn{3}{|c|}{$200^{\circ} \mathrm{C}$} \\
\hline & & 20 & 40 & 60 & 20 & 40 & 60 & 20 & 40 & 60 \\
\hline $\begin{array}{c}\text { POL } \\
\text { (unheated) }\end{array}$ & $9.47 \pm 0.25$ & & & & & & & & & \\
\hline $\begin{array}{c}\text { POL } \\
\text { (unblended) }\end{array}$ & & $12.43 \pm 0.00$ & $12.87 \pm 0.00$ & $13.49 \pm 0.00$ & $17.82 \pm 0.69$ & $17.52 \pm 0.00$ & $19.33 \pm 0.00$ & $8.52 \pm 0.69$ & $7.03 \pm 0.00$ & $12.98 \pm 0.02$ \\
\hline $\begin{array}{c}\text { PKO } \\
\text { (unheated) }\end{array}$ & $2.88 \pm 0.00$ & & & & & & & & & \\
\hline $\begin{array}{c}\text { PKO } \\
\text { (unblended) }\end{array}$ & & $1.93 \pm 0.00$ & $1.94 \pm 0.00$ & $1.60 \pm 0.00$ & $2.41 \pm 0.00$ & $4.12 \pm 0.00$ & $11.57 \pm 0.00$ & $8.62 \pm 0.00$ & $9.64 \pm 0.00$ & $9.44 \pm 0.00$ \\
\hline $\begin{array}{c}\text { POL:PKO } \\
(80: 20)\end{array}$ & & $11.48 \pm 0.00$ & $11.25 \pm 0.00$ & $11.22 \pm 0.00$ & $12.06 \pm 0.00$ & $12.06 \pm 0.00$ & $14.38 \pm 0.00$ & $\begin{array}{c}10.30 \pm 0.0 \\
0\end{array}$ & $8.61 \pm 0.00$ & $7.12 \pm 0.00$ \\
\hline $\begin{array}{c}\text { POL:PKO } \\
(60: 40)\end{array}$ & & $7.41 \pm 0.00$ & $7.48 \pm 0.00$ & $6.88 \pm 0.00$ & $8.77 \pm 0.00$ & $9.67 \pm 0.00$ & $10.50 \pm 0.00$ & $6.53 \pm 0.00$ & $5.55 \pm 0.00$ & $6.52 \pm 0.00$ \\
\hline $\begin{array}{l}\text { PKO:POL } \\
(80: 20)\end{array}$ & & $1.90 \pm 0.00$ & $1.88 \pm 0.00$ & $2.11 \pm 0.02$ & $2.53 \pm 0.00$ & $3.78 \pm 0.00$ & $6.55 \pm 0.02$ & $\begin{array}{c}11.14 \pm 0.0 \\
0\end{array}$ & $11.70 \pm 0.10$ & $11.61 \pm 0.00$ \\
\hline $\begin{array}{l}\text { PKO:POL } \\
(60: 40)\end{array}$ & & $2.63 \pm 0.10$ & $3.08 \pm 0.00$ & $2.69 \pm 0.00$ & $3.48 \pm 0.00$ & $4.19 \pm 0.01$ & $4.43 \pm 0.00$ & $4.51 \pm 0.00$ & $5.19 \pm 0.00$ & $5.52 \pm 0.00$ \\
\hline
\end{tabular}




\section{E. Totox Value}

This is used to describe total oxidation to which an oil sample has been exposed. As the peroxide values increased in Table 9, there were corresponding increases in totox values (Table 10). Anisidine value is often used in conjunction with peroxide value to calculate the so called total oxidation or totox value [29]. The totox value of unheated palm olein was $20.70 \mathrm{mg} / \mathrm{g}$. When heated, the value increased to $26.46 \mathrm{mg} / \mathrm{g}$. Unheated palm kernel oil had a totox value of $6.76 \mathrm{mg} / \mathrm{g}$ and when heated its totox value reduced to $4.96 \mathrm{mg} / \mathrm{g}$. Later at a higher temperature of $200{ }^{\circ} \mathrm{C}$, it drastically increased to $34.44 \mathrm{mg} / \mathrm{g}$. The increased observed were indicators of the increases of PV and P-AnV. This indicates that high temperature degrades PKO which is saturated. Most of the blended oil had comparatively lower totox values at high temperature of $200{ }^{\circ} \mathrm{C}$. Temperature and time effects on unblended PKO and higher blends of PKO were minimal at lower temperature. Initial reduction of totox value could be attributed to loss of volatile primary oxidation products such as aldehydes and ketone compounds, while the latter increase at elevated temperature reflected a larger scale of decomposition of $\beta$-carotenoids and other oil components. Totox value encompasses total oil quality with respect to the oxidation status and degradation products formed from previous oxidation. The lower the totox value, the better is the quality of the oil [28].

TABLE 10: EFFECTS OF HEATING PALM OLEIN, PALM KERNEL OIL AND THEIR BLENDS AT $100^{\circ} \mathrm{C}, 150^{\circ} \mathrm{C}$ AND $200^{\circ} \mathrm{C}$ ON THE TOTOX VALUES (MG/G)

\begin{tabular}{|c|c|c|c|c|c|c|c|c|c|c|}
\hline Temperature & \multirow{2}{*}{ Control } & \multicolumn{3}{|c|}{$100^{\circ} \mathrm{C}$} & \multicolumn{3}{|c|}{$150^{\circ} \mathrm{C}$} & \multicolumn{3}{|c|}{$200^{\circ} \mathrm{C}$} \\
\hline Time (mins) & & 20 & 40 & 60 & 20 & 40 & 60 & 20 & 40 & 60 \\
\hline POL unheated(mg/g) & $20.70 \pm 0.00$ & & & & & & & & & \\
\hline POL unblended & & $26.46 \pm 0.00$ & $27.31 \pm 0.00$ & $28.34 \pm 0.22$ & $37.02 \pm 1.35$ & $36.54 \pm 0.00$ & $39.64 \pm 0.03$ & $18.84 \pm 1.35$ & $15.26 \pm 0.00$ & $28.60 \pm 0.00$ \\
\hline PKO unheated & $6.76 \pm 0.00$ & & & & & & & & & \\
\hline PKO unblended & & $4.96 \pm 0.06$ & $4.96 \pm 0.00$ & $4.20 \pm 0.00$ & $6.12 \pm 0.00$ & $9.34 \pm 0.00$ & $33.48 \pm 0.00$ & $34.44 \pm 0.00$ & $40.44 \pm 0.00$ & $31.40 \pm 0.00$ \\
\hline POL:PKO(80:20) & & $25.56 \pm 0.00$ & $27.40 \pm 0.00$ & $23.80 \pm 0.00$ & $23.94 \pm 0.00$ & $27.52 \pm 0.00$ & $25.60 \pm 0.00$ & $32.89 \pm 0.01$ & $30.24 \pm 0.00$ & $27.48 \pm 0.00$ \\
\hline POL:PKO(60:40) & & $16.42 \pm 0.00$ & $16.16 \pm 0.00$ & $16.06 \pm 0.00$ & $20.24 \pm 0.00$ & $22.74 \pm 0.00$ & $24.10 \pm 0.00$ & $21.86 \pm 0.00$ & $16.70 \pm 0.00$ & $22.64 \pm 0.00$ \\
\hline PKO:POL(80:20) & & $4.90 \pm 0.00$ & $4.70 \pm 0.00$ & $5.01 \pm 0.00$ & $6.0 \pm 0.00$ & $9.56 \pm 0.00$ & $25.68 \pm 17.59$ & $28.08 \pm 0.00$ & $30.60 \pm 0.17$ & $30.92 \pm 0.00$ \\
\hline PKO:POL(60:40) & & $6.40 \pm 1.00$ & $7.16 \pm 0.00$ & $6.38 \pm 0.00$ & $8.06 \pm 0.00$ & $9.47 \pm 0.00$ & $9.78 \pm 0.00$ & $11.62 \pm 0.00$ & $13.58 \pm 0.00$ & $13.54 \pm 0.00$ \\
\hline
\end{tabular}

\section{F. Viscosity Values}

The viscosities of the various unheated oils and their blends are presented in Table 11. Untreated sample of palm olein had a viscosity of $36.40 \mathrm{PaS}$ and palm kernel oil 40.00 $\mathrm{PaS}$. The viscosities of unheated palm kernel oil were higher than that of unheated palm olein. This could be related to the degree of saturation of the oils which was in the order of saturation of the oils PKO>POL. Heating reduced the viscosities of the blends from $36.77 \mathrm{PaS}$ at $100^{\circ} \mathrm{C}$ for $20 \mathrm{mins}$ to $34.88 \mathrm{PaS}$ at $200^{\circ} \mathrm{C}$ for $60 \mathrm{mins}$ for blends of (POL: PKO $80: 20$ ) and blends of (PKO: POL $80: 20$ ) at $100^{\circ} \mathrm{C}$ for $20 \mathrm{mins}$ was $39.84 \mathrm{PaS}$ was reduced to $36.60 \mathrm{PaS}$ at $200{ }^{\circ} \mathrm{C}$ for 60 mins. Increase in temperature enhances freedom of movement of the molecules and reduces intermolecular attraction and frictional forces so that the layers of the liquid pass more easily over one another; this leads to a reduction in viscosity. As the temperature to which the oil samples were exposed increased remarkably there were decreases in the viscosities of the oil. This is not unexpected; high temperature (high caloric input) may serve to energize and move the oil molecules apart more easily and therefore decrease their resistance to flow. Also, viscosities of the oil blends decreased as the proportion of olein in the various blends increased. Accordingly, the effect of saturation on the viscosity values is again obvious. Less friction between the fatty acid chains and the molecular flexibility of fatty acid component could be another explanation for reduced viscosities at higher temperatures of exposures of the oils. Viscosity is thus a function of molecular size and molecular packing or orientation. This agrees with the observation in the present studies. High temperature may thermocatalytically degrade fatty acids into low molecular weight species and therefore decrease viscosities of oils.

TABLE 11: EFFECTS OF HEATING PALM OLEIN, PALM KERNEL OIL AND THEIR BLENDS AT $100^{\circ} \mathrm{C}, 1500^{\circ} \mathrm{C}$ AND $200^{\circ} \mathrm{C}$ ON THE VISCOSITY VALUES (PAS)

\begin{tabular}{|c|c|c|c|c|c|c|c|c|c|c|}
\hline \multirow{2}{*}{$\begin{array}{l}\text { Temperature } \\
\text { Time (mins) }\end{array}$} & \multirow[t]{2}{*}{ Control } & \multicolumn{3}{|c|}{$100^{\circ} \mathrm{C}$} & \multicolumn{3}{|c|}{$150^{\circ} \mathrm{C}$} & \multicolumn{3}{|c|}{$200^{\circ} \mathrm{C}$} \\
\hline & & 20 & 40 & 60 & 20 & 40 & 60 & 20 & 40 & 60 \\
\hline POL(unheated) & $36.40 \pm 0.09$ & & & & & & & & & \\
\hline POL(unblended) & & $37.00 \pm 0.02$ & $36.84 \pm 0.99$ & $36.54 \pm 0.91$ & $36.44 \pm 1.00$ & $36.30 \pm 0.80$ & $36.26 \pm 3.04$ & $35.34 \pm 2.00$ & $35.20 \pm 0.19$ & $35.15 \pm 0.10$ \\
\hline PKO (unheated) & $40.00 \pm 0.02$ & & & & & & & & & \\
\hline PKO unblended & & $40.00 \pm 0.03$ & $39.02 \pm 0.05$ & $39.33 \pm 0.07$ & $38.98 \pm 0.03$ & $38.50 \pm 0.02$ & $38.09 \pm 0.07$ & $37.88 \pm 0.10$ & $37.40 \pm 0.04$ & $37.00 \pm 0.17$ \\
\hline POL: PKO (80:20) & & $36.77 \pm 0.06$ & $36.04 \pm 0.32$ & $36.00 \pm 0.01$ & $36.25 \pm 0.11$ & $35.77 \pm 2.00$ & $35.97 \pm 0.57$ & $35.15 \pm 0.88$ & $34.67 \pm 0.35$ & $34.88 \pm 0.12$ \\
\hline POL: PKO (60:40) & & $37.94 \pm 0.95$ & $36.08 \pm 0.63$ & $36.50 \pm 0.15$ & $36.10 \pm 3.25$ & $35.86 \pm 0.57$ & $35.66 \pm 0.81$ & $35.10 \pm 0.01$ & $34.77 \pm 2.03$ & $34.56 \pm 1.12$ \\
\hline PKO :POL (80:20) & & $39.84 \pm 0.95$ & $38.15 \pm 1.42$ & $38.50 \pm 0.03$ & $38.00 \pm 0.60$ & $37.88 \pm 2.66$ & $37.78 \pm 0.06$ & $37.00 \pm 1.20$ & $36.78 \pm 8.00$ & $36.60 \pm 0.40$ \\
\hline PKO:POL (60:40) & & $37.16 \pm 0.01$ & $36.65 \pm 3.17$ & $37.02 \pm 0.02$ & $36.65 \pm 1.75$ & $36.55 \pm 0.30$ & $36.57 \pm 0.75$ & $35.55 \pm 0.09$ & $35.40 \pm 0.23$ & $35.47 \pm 0.55$ \\
\hline
\end{tabular}




\section{G. Cloud Point}

Cloud point is the temperature at which crystallization is induced, in oils. It is one of the indices used to study the physical properties of fats and oils. It is related to the unsaturation of oil and its resistance to crystallization. Crystallization of oils is of importance in processes, such as fractionation, and in determining the physical properties of oils and their products [29]-[30]. Oil samples are usually clear and transparent at temperature above cloud point, but they appear cloudy at their cloud points and below when crystallization occurs. The cloud points of the oil samples in this study are presented in Table 12. Untreated palm olein had a cloud point of $9.80{ }^{\circ} \mathrm{C}$ and for palm kernel oil it was $17.03{ }^{\circ} \mathrm{C}$. Cloud point followed this order of PKO>POL while the order of unsaturation is $\mathrm{POL}>\mathrm{PKO}$. Heating palm olein at $100^{\circ} \mathrm{C}$ led to slight increase in cloud point to $9.97^{\circ} \mathrm{C}$. Blending palm olein with palm kernel oil resulted in a decrease in the cloud points of the PKO samples. As exposure temperature increased, there were increases in the cloud points of the oils. The acceptable cloud point for palm olein is between $6.6-14.3^{\circ} \mathrm{C}[5]$; the cloud point of palm olein used in this study was within the range. The higher cloud points for palm kernel oil obtained in this study can be attributed to their degrees of saturation. Blending palm olein with PKO resulted in a reduction in cloud point arising from modification of the unsaturated contents of the blends; palm olein contains higher levels of unsaturated fatty acids than PKO. Fat crystal formation is reduced in the blends with increasing levels of palm olein. The more unsaturated a sample is, the lower the cloud point. Knowledge of the cloud point of oils is important in determining the appropriate storage temperature that will prevent storage crystallization in the oil and products based on them. Properties such as rheological, consistency, mouth feel, graininess, solid-liquid ratio and dilatometric response may be affected by cloud point values.

TABLE 12: EFFECTS OF HEATING PALM OLEIN, PALM KERNEL OIL AND THEIR BLENDS AT $100{ }^{\circ} \mathrm{C}, 150^{\circ} \mathrm{C}$ AND $200^{\circ} \mathrm{C}$ ON THE CLOUD POINT

\begin{tabular}{|c|c|c|c|c|c|c|c|c|c|c|}
\hline \multirow{2}{*}{$\begin{array}{l}\text { Temperature } \\
\text { Time (mins) }\end{array}$} & \multirow[t]{2}{*}{ Control } & \multicolumn{3}{|c|}{$100^{\circ} \mathrm{C}$} & \multicolumn{3}{|c|}{$150^{\circ} \mathrm{C}$} & \multicolumn{3}{|c|}{$200^{\circ} \mathrm{C}$} \\
\hline & & 20 & 40 & 60 & 20 & 40 & 60 & 20 & 40 & 60 \\
\hline $\begin{array}{c}\text { POL } \\
\text { (unheated) }\end{array}$ & $9.80 \pm 0.10$ & & & & & & & & & \\
\hline $\begin{array}{c}\text { POL } \\
\text { (unblended) }\end{array}$ & & $9.97 \pm 0.21$ & $10.06 \pm 0.06$ & $10.10 \pm 0.10$ & $9.77 \pm 0.06$ & $9.60 \pm 0.10$ & $11.23 \pm 0.25$ & $9.80 \pm 0.00$ & $10.63 \pm 0.15$ & $11.96 \pm 0.45$ \\
\hline $\begin{array}{c}\text { PKO } \\
\text { (unheated) }\end{array}$ & $17.03 \pm 0.06$ & & & & & & & & & \\
\hline $\begin{array}{c}\text { PKO } \\
\text { (unblended) }\end{array}$ & & $21.13 \pm 0.06$ & $19.26 \pm 0.06$ & $17.56 \pm 0.12$ & $15.03 \pm 0.15$ & $16.87 \pm 0.12$ & $21.36 \pm 0.15$ & $16.46 \pm 0.60$ & $18.90 \pm 0.10$ & $18.83 \pm 0.06$ \\
\hline $\begin{array}{l}\text { POL:PKO } \\
(80: 20)\end{array}$ & & $11.26 \pm 0.06$ & $8.90 \pm 0.10$ & $9.37 \pm 0.21$ & $10.20 \pm 0.10$ & $8.30 \pm 0.00$ & $9.90 \pm 0.10$ & $8.87 \pm 0.15$ & $9.37 \pm 0.45$ & $9.13 \pm 0.06$ \\
\hline $\begin{array}{l}\text { POL:PKO } \\
(60: 40)\end{array}$ & & $7.87 \pm 0.12$ & $9.17 \pm 0.15$ & $10.23 \pm 0.06$ & $10.00 \pm 0.20$ & $13.63 \pm 0.15$ & $8.80 \pm 0.10$ & $7.77 \pm 0.06$ & $9.60 \pm 0.10$ & $8.40 \pm 0.10$ \\
\hline $\begin{array}{l}\text { PKO:POL } \\
(80: 20)\end{array}$ & & $13.46 \pm 0.31$ & $15.43 \pm 0.06$ & $16.36 \pm 0.12$ & $15.16 \pm 0.35$ & $16.47 \pm 0.06$ & $14.26 \pm 0.06$ & $16.47 \pm 0.01$ & $16.23 \pm 0.0$ & $14.80 \pm 0.00$ \\
\hline $\begin{array}{l}\text { PKO:POL } \\
(60: 40)\end{array}$ & & $15.37 \pm 0.55$ & $14.23 \pm 0.06$ & $11.80 \pm 0.00$ & $14.47 \pm 0.06$ & $10.97 \pm 0.06$ & $12.83 \pm 0.06$ & $12.50 \pm 0.00$ & $11.97 \pm 0.06$ & $18.33 \pm 0.06$ \\
\hline
\end{tabular}

\section{H. Slip Melting Point}

Slip melting point is widely used to characterise the melting and solidification properties of oils and fats. For a pure substance, a specific melting point is a criterion of purity. However, fats and oils are variable mixtures of triglycerides, having melting point ranges [31]. The results in Table 13 show that the initial slip melting point of palm olein was $11.50{ }^{\circ} \mathrm{C}$ for palm kernel oil $29.33{ }^{\circ} \mathrm{C}$, respectively. The acceptable melting point limit [32] for palm olein is 19.40 $23.5^{\circ} \mathrm{C}$; for palm kernel oil $23.0-30.0^{\circ} \mathrm{C}$. The melting point result for palm olein was below the [33] value for palm olein, while that of palm kernel oil was within the [33] limit. When palm olein and palm kernel oil were heated, there were increases in the melting points of palm olein and a decrease in palm kernel oil. The blends showed substantial increases in melting points when palm olein was blended with palm kernel oil at different ratios, increasing with the proportion of palm kernel oil included. The high percentage of medium chain saturated fatty acid is principally responsible for giving palm kernel oil sharp melting point. The melting point of palm olein was lower because it is highly unsaturated as indicated by higher iodine value as observed in Table 7 . The decrease in melting point of the blends indicates that blending palm olein (unsaturated) with palm kernel oil (saturated) yielded blends with lower melting points.

\section{Colour Values}

Colour is one of the subjective and easily measured parameters used to determine the quality of oils. It, generally, ranges from colourless to very dark. Tables 14-16 show the initial colours of the oils. Palm kernel oil had an initial value of 3.00R and 70.00Y; palm olein 2.97R and 57.00Y. When the oils were heated, there were initial increases in red units and decreases in yellow units for palm olein and palm kernel oil. At a higher temperature $200{ }^{\circ} \mathrm{C}$, there were decreases in colour in the oils (palm olein and palm kernel oil). Palm kernel oil was dark yellow and showed greater decrease in red and yellow units compared to palm olein. As the oil was heated it became lighter and had an attractive golden colour. Blending palm kernel oil with palm olein gave a lighter oil colour. As the heating time increased, the colour became lighter as is evident in Tables 14-16.The red to yellow colour change in palm oil at higher temperature is attributed to decomposition of the carotenoids content ( $\beta$ - carotene, for example) which is actually a precursor of vitamin A. This vitamin not only act has antioxidant activity, it prevents night blindness and xerophthalmia. Therefore, the red and yellow colour in palm olein is not just of aesthetic value, but also of nutritional and health importance. The blended oils had increased red units for higher blends of palm olein, while higher blends of PKO had low red units which may be due to 
the inherently lower levels of carotenoids in the palm olein. As temperature and time increased, there was a reduction in red and yellow units of unblended PKO, palm olein and its blends

TABEL 13: EFFECTS OF HEATING PALM OLEIN, PALM KERNEL OIL AND THEIR BLENDS AT $100^{\circ} \mathrm{C}, 150^{\circ} \mathrm{C}$ AND $200^{\circ} \mathrm{C}$ ON THE SLIP MELTING POINTS ( ${ }^{\circ} \mathrm{C}$ )

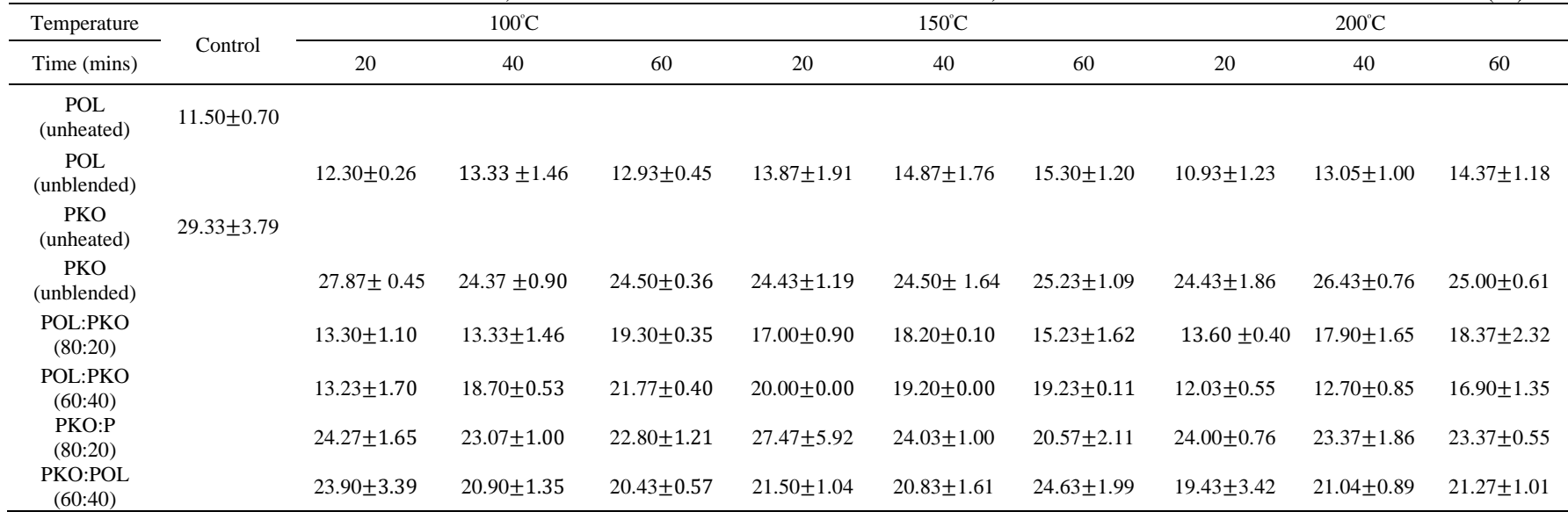

TABLE 14: EFFECTS OF HEATING PALM OLEIN, PALM KERNEL OIL, AND THEIR BLENDS AT $100^{\circ} \mathrm{C}$, IT EFFECT ON THEIR COLOURS

\begin{tabular}{ccccc}
\hline Colour & $\begin{array}{c}\text { Temperature } \\
\text { / Time }\end{array}$ & Red & Yellow & Green \\
\hline POL unheated & $100^{\circ} \mathrm{C}$ & $2.97 \pm 0.06$ & $57.00 \pm 0.00$ & $0.00 \pm 0.00$ \\
& $20 \mathrm{mins}$ & $3.00 \pm 0.00$ & $51.00 \pm 0.00$ & $0.00 \pm 0.00$ \\
POL unblended & $40 \mathrm{mins}$ & $3.00 \pm 0.00$ & $51.00 \pm 0.00$ & $0.00 \pm 0.00$ \\
& $60 \mathrm{mins}$ & $3.00 \pm 0.00$ & $51.00 \pm 0.00$ & $0.00 \pm 0.00$ \\
& $20 \mathrm{mins}$ & $5.67 \pm 0.98$ & $71.20 \pm 2.08$ & $1.20 \pm 2.08$ \\
POL: PKO (80:20) & $40 \mathrm{mins}$ & $5.20 \pm 0.00$ & $70.00 \pm 0.00$ & $0.00 \pm 0.00$ \\
& $60 \mathrm{mins}$ & $4.80 \pm 0.00$ & $70.00 \pm 0.00$ & $0.00 \pm 0.00$ \\
& $20 \mathrm{mins}$ & $4.80 \pm 0.00$ & $70.47 \pm 0.15$ & $0.67 \pm 0.21$ \\
POL: PKO (60:40) & $60 \mathrm{mins}$ & $3.37 \pm 0.12$ & $39.67 \pm 0.21$ & $0.50 \pm 0.77$ \\
& $40 \mathrm{mins}$ & $2.87 \pm 0.06$ & $27.50 \pm 0.17$ & $0.47 \pm 0.15$ \\
PKO unheated & & $3.00 \pm 0.00$ & $70.00 \pm 0.00$ & $0.00 \pm 0.00$ \\
& $20 \mathrm{mins}$ & $3.27 \pm 0.21$ & $70.00 \pm 0.00$ & $0.47 \pm 0.15$ \\
PKO unblended & $40 \mathrm{mins}$ & $3.00 \pm 0.10$ & $70.47 \pm 0.15$ & $0.00 \pm 0.00$ \\
& $60 \mathrm{mins}$ & $1.13 \pm 0.06$ & $11.23 \pm 1.66$ & $0.00 \pm 0.00$ \\
& $20 \mathrm{mins}$ & $2.80 \pm 0.11$ & $70.00 \pm 0.00$ & $3.60 \pm 0.00$ \\
PKO:POL(80:20 ) & $40 \mathrm{mins}$ & $2.70 \pm 0.00$ & $70.00 \pm 0.00$ & $0.00 \pm 0.00$ \\
& $60 \mathrm{mins}$ & $2.67 \pm 0.00$ & $6.53 \pm 0.00$ & $0.00 \pm 0.00$ \\
& $20 \mathrm{mins}$ & $2.20 \pm 0.06$ & $70.00 \pm 0.00$ & $0.00 \pm 0.00$ \\
PKO:POL (60:40) & $40 \mathrm{mins}$ & $2.13 \pm 0.00$ & $70.00 \pm 0.00$ & $0.00 \pm 0.00$ \\
& $60 \mathrm{mins}$ & $2.10 \pm 0.00$ & $70.00 \pm 0.00$ & $0.00 \pm 0.00$ \\
\hline
\end{tabular}

TABLE 15: EFFECTS OF HEATING PALM OLEIN, PALM KERNEL OIL AND THEIR BLENDS AT $150^{\circ} \mathrm{C}$, ON THEIR COLOURS

\begin{tabular}{ccccc}
\hline Colour & $\begin{array}{c}\text { Temperature/ } \\
\text { Time }\end{array}$ & Red & Yellow & Green \\
\hline POL unheated & $150{ }^{\circ} \mathrm{C}$ & $2.97 \pm 0.06$ & $57.00 \pm 0.00$ & $0.00 \pm 0.00$ \\
& $20 \mathrm{mins}$ & $5.50 \pm 0.00$ & $70.00 \pm 0.00$ & $0.00 \pm 0.00$ \\
POL & $40 \mathrm{mins}$ & $4.93 \pm 0.12$ & $70.00 \pm 0.00$ & $0.00 \pm 0.00$ \\
unblended & $60 \mathrm{mins}$ & $4.37 \pm 0.06$ & $70.00 \pm 0.00$ & $0.00 \pm 0.00$ \\
& $20 \mathrm{mins}$ & $5.07 \pm 0.06$ & $70.00 \pm 0.00$ & $0.00 \pm 0.00$ \\
POL:PKO & $40 \mathrm{mins}$ & $4.47 \pm 0.23$ & $70.00 \pm 0.00$ & $0.00 \pm 0.00$ \\
(80:20) & $60 \mathrm{mins}$ & $3.47 \pm 0.46$ & $46.00 \pm 2.78$ & $0.00 \pm 0.00$ \\
& $20 \mathrm{mins}$ & $6.67 \pm 0.98$ & $71.20 \pm 2.08$ & $2.40 \pm 2.08$ \\
POL: PKO & $40 \mathrm{mins}$ & $5.70 \pm 1.04$ & $71.40 \pm 2.08$ & $1.20 \pm 2.08$ \\
(60:40) & $60 \mathrm{mins}$ & $2.93 \pm 0.06$ & $29.77 \pm 1.07$ & $1.10 \pm 0.10$ \\
& & $3.00 \pm 0.00$ & $70.00 \pm 0.00$ & $0.00 \pm 0.00$ \\
PKO unheated & $20 \mathrm{mins}$ & $2.90 \pm 1.04$ & $71.73 \pm 1.50$ & $0.00 \pm 0.00$ \\
PKO & $40 \mathrm{mins}$ & $2.33 \pm 0.12$ & $70.00 \pm 0.00$ & $0.00 \pm 0.00$ \\
unblended & $60 \mathrm{mins}$ & $2.01 \pm 1.04$ & $53: 00 \pm 1.50$ & $3.60 \pm 0.00$ \\
& $20 \mathrm{mins}$ & $2.10 \pm 0.00$ & $70.00 \pm 0.00$ & $0.00 \pm 0.00$ \\
PKO: POL & $40 \mathrm{mins}$ & $1.90 \pm 0.00$ & $39.00 \pm 0.00$ & $0.00 \pm 0.00$ \\
(80:20) & $60 \mathrm{mins}$ & $1.23 \pm 0.06$ & $13.00 \pm 1.00$ & $0.00 \pm 0.00$ \\
& $20 \mathrm{mins}$ & $1.90 \pm 0.00$ & $70.00 \pm 0.00$ & $0.00 \pm 0.00$ \\
PKO: POL & $40 \mathrm{mins}$ & $1.77 \pm 0.06$ & $24.67 \pm 1.15$ & $0.00 \pm 0.00$ \\
(60:40) & $60 \mathrm{mins}$ & $1.00 \pm 0.00$ & $6.13 \pm 0.12$ & $0.00 \pm 0.00$ \\
\hline
\end{tabular}

TABLE 16: EFFECTS OF HEATING PALM OLEIN, PALM KERNEL OIL AND

\begin{tabular}{ccccc}
\multicolumn{5}{c}{ THEIR BLENDS AT $150{ }^{\circ} \mathrm{C}$, ON THEIR COLOURS } \\
\hline Colour & $\begin{array}{c}\text { Temperature/ } \\
\text { Time }\end{array}$ & Red & Yellow & Green \\
\hline POL & $200^{\circ} \mathrm{C}$ & $2.97 \pm 0.06$ & $57.00 \pm 0.00$ & $0.00 \pm 0.00$ \\
unheated & $20 \mathrm{mins}$ & $2.30 \pm 0.00$ & $49.33 \pm 2.89$ & $0.00 \pm 0.00$ \\
POL & $40 \mathrm{mins}$ & $2.10 \pm 0.00$ & $39.00 \pm 0.00$ & $0.00 \pm 0.00$ \\
unblended & $60 \mathrm{mins}$ & $2.10 \pm 0.00$ & $28.33 \pm 0.58$ & $0.00 \pm 0.00$ \\
& $20 \mathrm{mins}$ & $3.10 \pm 0.95$ & $32.03 \pm 1.72$ & $1.37 \pm 1.94$ \\
POL:PKO & $40 \mathrm{mins}$ & $2.70 \pm 0.10$ & $29.27 \pm 0.61$ & $0.60 \pm 0.20$ \\
(80:20) & $60 \mathrm{mins}$ & $2.60 \pm 0.00$ & $26.30 \pm 0.00$ & $0.30 \pm 0.00$ \\
& $20 \mathrm{mins}$ & $4.20 \pm 0.00$ & $29.60 \pm 0.00$ & $3.60 \pm 0.00$ \\
POL: PKO & $40 \mathrm{mins}$ & $3.17 \pm 0.06$ & $24.03 \pm 0.06$ & $2.03 \pm 0.06$ \\
(60:40) & $60 \mathrm{mins}$ & $2.23 \pm 0.12$ & $21.23 \pm 0.21$ & $0.13 \pm 0.23$ \\
& & $3.00 \pm 0.00$ & $70.00 \pm 0.00$ & $0.00 \pm 0.00$ \\
PKO & & $1.60 \pm 0.00$ & $4.40 \pm 0.10$ & $1.00 \pm 0.10$ \\
unheated & $20 \mathrm{mins}$ & $1.37 \pm 0.06$ & $3.33 \pm 0.12$ & $0.67 \pm 0.06$ \\
PKO & $40 \mathrm{mins}$ & $1.17 \pm 0.06$ & $2.93 \pm 0.12$ & $0.27 \pm 0.15$ \\
unblended & $60 \mathrm{mins}$ & $2.67 \pm 0.06$ & $3.17 \pm 0.06$ & $3.60 \pm 0.00$ \\
& $20 \mathrm{mins}$ & $1.40 \pm 0.10$ & $2.67 \pm 1.15$ & $0.00 \pm 0.00$ \\
PKO:POL & $40 \mathrm{mins}$ & $0.83 \pm 0.06$ & $0.33 \pm 0.06$ & $0.00 \pm 0.00$ \\
(80:20) & $60 \mathrm{mins}$ & $2.80 \pm 0.00$ & $7.23 \pm 0.06$ & $0.00 \pm 0.00$ \\
& $20 \mathrm{mins}$ & $2.67 \pm 0.06$ & $7.23 \pm 0.06$ & $3.60 \pm 0.00$ \\
PKO:POL & $40 \mathrm{mins}$ & $0.80 \pm 0.00$ & $3.00 \pm 0.00$ & $2.40 \pm 2.08$ \\
(60:40) & $60 \mathrm{mins}$ & & &
\end{tabular}

\section{CONCLUSION}

The study examined the chemical changes in oil and the fatty acid composition of the oil when palm kernel oil was blended with palm olein. Heating is to improve the oil stability and determine its performance, stability before used in frying. Oil deterioration was relatively low across heating time and temperature except for heated palm kernel oil which showed rapid deterioration at elevated temperature. In some cases, the stability of oil blends (PKO/POL) was equivalent to that of palm olein. These findings provide useful information to oil blenders and consumers when looking for stable oil for industrial and domestic frying without the need to fully replace their preferable local oils. The chemical parameters and fatty acid composition show that the best blend is blend of PKO: POL (60:40). 


\section{ACKNOWLEDGEMENT}

Imoisi, O.B. thank University of Hull, UK for giving me laboratory space for my analysis and fatty acid profile carried out at Chemistry Department. My thanks also go to Analytical Chemistry Trust Fund (ACTF) for providing the funds.

\section{REFERENCES}

[1] M. Younis., S. T. H. Talpur., S. A. Sherazi., M. I. Mahesar and A. K. Bhanger. (2011). Consequence of commercial fish frying on some quality parameters of oil with special reference to trans-fat. Int. J. of Food Properties, 14, 1124- 1135.

[2] S. Rizwana (2008): Analytical tool for rapid analysis of edible oils. Masters Thesis Chemical Engineering.

[3] S.M. AbdulKarim., M.W. Myat and H.M. Ghazali (2010b). Sensory and Physicochemical Qualities of Palm Olein and Sesame Seed Oil Blends during Frying of Banana Chips, J. of Agricultural Science, 2(4), 18-29

[4] Hartly (1988): The Oil Palm, $3^{\text {rd }}$ edn. London Longman.

[5] PORIM (2011) at palm oil world.org

[6] D.O. Edem (2002): Palm oil. Biochemical, psysiological, nutritional, haematological and toxicological aspects. A review Plant Foods for Human Nutrition. 57, 319-341.

[7] M. Murakoshi., H. Nishino,, Y. Satomi., J. Takayasu., T. Hasegawa., H. Tokuda., A. Iwashima J. Aokuzumi., H. Okabe and H. Kitono (1992): Potent preventive action of calpha - carotene agaist carcinogenesis: spontaneous liver carcinogenesis and promoting stage of lung and skin carcinogenesis in mice are suppressed more effectively by alpha-carotene then by beta carotene. Cancer. Res 52 , 6583-6587.

[8] Y.M. Choo and A.N. MA (2000). Extraction of palm-pressed fibre oil using super critical fluid technology. Proc. of the 2000 National Siminar on Palm Oil Milling, Refining Technology, Quality and Environmental.

[9] Y. Basiron (1995): Palm oil. In: Bailey's Industrial Oil and Fat Products, Vol. 5, $5^{\text {th }}$ Edn. (Y.H. Hui, Ed). Wiley, New York.

[10] S. Gulla and K. Waghray (2011): Effect of storage on physicot chemical characteristics and fatty acid composition of selected oil blends. JLS, 3 (1): 35-46.

[11] J.P. White (2000): fatty acids in oil seeds. In: C.K. Chow (Ed). Fatty Acids in Foods and their Health Implications. New York. Marcel Dekker Inc. pp. 209-238

[12] M. Naghshineh., A.A. Ariffin., H.M. Ghazali., H. Mirhosseini and A.S. Mohammad (2010): Effect of Saturated/Unsaturated Fatty Acid Ratio on Physicochemical Properties of Palm Olein-Olive Oil Blend. Journal of the American Oil Chemists' Society, 87(3), 255-262.

[13] D.Shankar., K.V. Pugalend.i, C. Sambandam and M.R. Rao (2003): Sesame oil helps reduce close of blood pressure lowing- medicine. From <http://www.americanheart.org/presenter.

[14] J. Adhikari., (2002). Enriching of Oils RBO's Midas touch.SAARC Oils and Fats Today, August: 15-17.

[15] IUPAC (1979): Gas chromatographic method for determination of fatty acid composition. J. Assoc. Official Anal. Chem. .62(4):709-21.

[16] AOCS (2017). Official Method of Analysis.

[17] AOAC (2010). Official Method of Analysis. $18^{\text {th }}$ ed. Associ. Office. Anal. Chem. Arlington, VA.

[18] A. Noh., N. Rajanaidu., A. Kushairi., Y. Mohd Rafii., A. Mohd Din., Z.A. Mohd Isa and G. Saleh, (2009): Variability in fatty and acid composition, iodine value and carotene in the MPOB oil palm germplasm collection from Angola, Journal of Oil Palm Research, 14, (2), $18-23$.

[19] C. Tompkins and E.G. Perkins (2000): Frying performance of lowlinolenic acid soybean oil. J. of the A. Chem. Soc., 77(3): 223-229.

[20] B. Matthaus (2006): Utilization of high oleic rape seed oil for deep fat frying of French fries compared to other common used edible oils. Euro. J. of Lipid Technol., 108, pp. 200-11.

[21] E. Choe and D.B. Min (2007). Chemistry of deep fat frying oils. J. Food Sci., 72, 77-86.

[22] N. Mahsa., A.A. Abdul., M.G. Hasanah., M. Hamed and S.M. Abdulkarim (2010): Effect of saturated / unsaturated acid ratio on physicochemical properties of palm olein oil blend. J.Am. Oil Chem. Soc. PP 87:255-262

[23] W.L.Siew., T.S. Tang and Y.A.Tan (1995): Methods of test for palm oil and palm oil products. PORIM test method. Palm Oil Research Institute of Malaysia, Bangi. pp.112-113.
[24] T.L. Mounts., K. Warner., G.R. List., W.E. Neff and R.F. Wilson (1997): Low linolenic acid soybean oils alternatives to frying oils. J. of the A. Oil Chem. Soc., 71, pp. 495-499.

[25] K. Warner (1997). Chemistry of frying fats in Akoh, C.C., Min, D. B (Eds.) Food Lipids: Chemistry, Nutrition and Biotechnology, p. 167 180, Marcel Dekker, Inc., New York.

[26] T.P. Pantzaris (1997): Criteria for comparing frying oils. In: Kochar, S.P. (edit). New developments in industrial frying. Bridgwater, U.K.S Barnes and Associates, PP. 73-90.

[27] S. Lalas and J. Tsaknis (2012): Characterization of moringaoleifera seed oil variety periyakulam - 1. J. Food Compound and Anal, 15: 65 -77 .

[28] W.L. Siew., F.C. OH and A.S.H. Ong (1985): Factors affecting cloud point analysis of palm oleins. J. Amer. Oil Chem. Soc. 62(6): 10361039.

[29] T.W. Wal., B. Saad and P.B. Lim (2009): Determination of totox value in palm olein using a FT - potentiometric analyzer. J. of Food Chem. 113: $285-290$

[30] M.S.A. Yusof., M. Rusnani. and I. Bazali (1995): Production of high carotene palm olein using moderate deodorization temperature. Palm oil development No. 25:7-9.

[31] AOCS (2006). Physical and chemical characteristics of oils, fats and waxes. Am. Oil Chem. Soc. Champaign. IL. 